UDC 624.014.2:624.078.46:624.042.062

\title{
THE EFFECT OF THE ACTUAL STIFFNESS OF BOLTED HINGED JOINTS ON THE BEARING CAPACITY OF THE ELEMENTS
}

\author{
V.V. Romaniuk, \\ Candidate of Technical Sciences \\ V.V. Supruniuk, \\ Candidate of Technical Sciences \\ L.I. Bezniuk, \\ Postgraduate Student \\ T.Y. Misyuk, \\ Postgraduate Student

\begin{abstract}
National University of Water and Environmental Engineering, 11, Soborna str., Rivne, Ukraine, 33024
\end{abstract}

DOI: $10.32347 / 2410-2547.2021 .107 .323-332$

\begin{abstract}
The article investigates the influence of partial stiffness of the hinge joint of singlespan and multi-span freely supported beams with lower structures on their stress-strain state under the action of vertical evenly distributed load. Joints of freely supported beams under the action of external load are opened on supports and mounting bolts interfere with their full opening, that is joints work as partially rigid. Knowing some initial parameters of ideally hinged joints, it is possible to establish what influence their change will have both on the calculation scheme of beams, and on calculation schemes of cross frames of frameworks of buildings and constructions, to which they enter, as a whole. The method of initial parameters was used to determine the influence of the resistance of the mounting bolts on the opening of the support joints on the stress state of the elements. The offered technique allows to define real rigidity of any bolted hinge connection taking into account its actual work and to adjust it stiffnesst by changing the diameter of the bolts, the strength of the material from which they are made, their number, distance between them, as well as use additional material resource by reducing the maximum stresses in the calculated cross sections. This is especially true of elements made of perforated profiles, because the change of stress-strain state in the support zones will cause redistribution of stresses in the calculated points of their cross sections, both on the supports and in the span of the beams. This must be taken into account by including certain coefficients in the calculation formulas, depending on the specific operating conditions.
\end{abstract}

Keywords: bolt, connection, bearing capacity, resistance, rigidity, hinge joint, beam.

Introduction. The design of buildings and structures for any purpose begins with the development of a spatial planning solution, due to the specified in the design task certain technological or functional requirements. Based on this decision, the basic dimensions and structural schemes of load-bearing structures, including the schemes of nodal joints, which can be made using assembly welding or joining bolts, are adopted in the first place. The presence of a carefully designed structural scheme allows us to make a design scheme of a single structure or frame as a whole, which takes into account the effect on the building of all external, both concentrated and evenly distributed loads. The development of structural and design schemes must take into account the 
type of node connections of the elements and the purpose of certain boundary conditions.

At present, in the current domestic and European design standards for steel structures $[1,2]$ the boundary conditions of bolted and welded joints are idealized, that is rigid, hinged fixed, hinged movable, etc., which does not fully correspond the actual conditions of their work and structures in general. If we consider single-span split and multi-span continuous beams, which rest on certain supports (below are beams, columns, etc.) and fastened to them with mounting bolts, then in calculations using an idealized calculation scheme, such a connection is considered hinged and bolts perform only the functions of beam retainer in the design position. In fact, under the action of external load beams are bent and as a result of their deflection bolts are stretched and interfere with free deformations on the supports, that is these supports become partially rigid, which affects to the redistribution of forces along the length of the beam, and, for example, rigid flange bolted connections, in turn, on the contrary, work as partially hinged. Theoretical and experimental studies [3-11] performed earlier, including by the authors of this work, confirm this.

From the correct consideration of the actual stiffness of the bolted joints depends not only their load-bearing capacity and deformability, but also the load-bearing capacity of the structural elements, connected in these nodes. In particular, the authors as a result of tests of a steel perforated arch with a rigid flange ridge node $[3,4,5]$ found a significant difference in stresses calculated theoretically and obtained experimentally, in cross sections near it (the difference was $56.6 \% \ldots 67.1 \%$.), and the pliability of the hinged single-span frame with rigid nodes [11] was $6 \% \ldots 10 \%$.

This can be explained by the pliability of the flange bolted joint, which was opened by the action in the node of bending moment and longitudinal force, and in theoretical calculations, this connection was taken absolutely rigid. As a result, the ridge node worked not as rigid, but partly hinged, and the actual calculation scheme of the double-hinged arch was partly three-hinged, and therefore the value of the bending moment in the node was less, than calculated earlier, due to its pliability. Experimental and theoretical studies $[3,5]$ found that the stiffness of the bolted connection was 0.412 compared to the stiffness of the ideal flange connection taken as a unit. It was also found that the rigidity of the node changes with the changing of parameters of its details.. So, for example, with changing of diameter of a bolt from 10 to 24 $\mathrm{mm}$ rigidity changes accordingly from 0,412 to 0,897 .

Purpose and Research Methods. The purpose of these studies is to theoretically determine the actual stiffness of bolted joints of steel structures, as well as to develop an effective method for determining the influence of resistance of mounting bolts on the opening of hinged support units in particular and their stiffness in general.

To achieve this purpose, the method of initial parameters, the method of finite elements, implemented in the software package "Lira", as well as the 
results of numerous theoretical and experimental studies, performed by the authors.

Main Results. To study the effect of the stiffness of the hinge assembly on the stress-strain state of the elements, we can consider both single-span and multi-span beams, which perceive the vertical load $q$ evenly distributed in the span (Fig. 1). Fastening of beams to the lower constructions is accepted hinged according to the storey scheme of beams connections.

Since the design position of the beam is fixed by bolts, tensile forces arise in them due to the action of external load $q$ on this beam and they

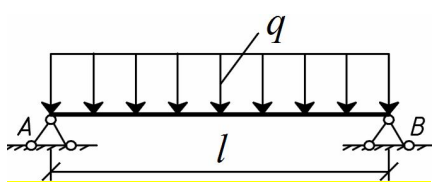

Fig. 1. The calculation scheme of singlesnan beam will interfere with the full opening of the support nodes, which, as a result, will become partially rigid. Knowing some initial parameters of ideally hinged nodes, it is possible to establish what influence their change will have both on the calculation scheme of a beam, and on the calculation scheme of a frame or a framework as a whole, and also on separate elements.

The calculanion scheme of the beam taking into account the actual stiffness of the support nodes is presented in Fig. 2.

To determine the magnitude of the opening of the hinged nodes the method of initial parameters is used

$$
\left.\begin{array}{l}
E I \theta_{x i}=E I \theta_{0}+\sum M_{x i}\left(x_{i}-a_{1}\right)+\sum F_{x i} \frac{\left(x_{i}-a_{2}\right)^{2}}{2}+\sum q_{x i} \frac{\left(x_{i}-a_{3}\right)^{3}}{6} \\
E I y_{x i}=E I y_{0}+E I \theta_{0} x_{i}+\sum M_{x i} \frac{\left(x_{i}-a_{1}\right)^{2}}{2}+\sum F_{x i} \frac{\left(x_{i}-a_{2}\right)^{3}}{6}+\sum q_{x i} \frac{\left(x_{i}-a_{3}\right)^{4}}{24}
\end{array}\right\},
$$

where is $\theta_{x i}, y_{x i}$ - the angle of rotation and deflection in the cross section of the element under consideration; $\theta_{0}, y_{0}$ - angle of rotation and deflection of the element at the beginning of the system (initial parameters); $M_{x i}, F_{x i}, q_{x i}-$ respectively concentrated moments, concentrated forces and the value of evenly distributed load, which are applied to the structure; $x_{i}$ - the distance from the beginning of the system to the cross section in which the deformation is calculated; $a_{1}, a_{2}, a_{3}$ - distances from the beginning of the system to the points of application respectively of concentrated moments, concentrated forces and to the beginning of areas of application of distributed load; $I$ - moment of inertia of the section; $E-$ modulus of elasticity of steel.

Taking the initial

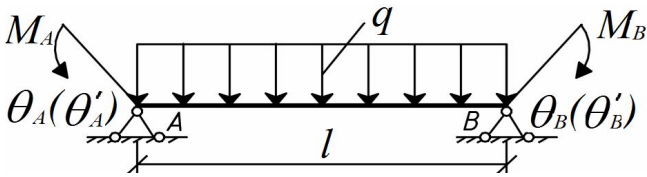

Fig. 2. The calculation scheme of the beam, taking into account the partial stiffness of the support nodes 
parameters, namely that the deflections of the beams on the supports, respectively in nodes $A$ and $B$ of the single-span beam or on all supports of the multi-span continuous beam, are zero, using the right part of formula (1) and taking the origin in node $A$, you can determine the angle of rotation in the idealized calculation scheme of the hinged node of the beam on the support.

$$
E I \theta_{A}=E I \theta_{B}=q \frac{l^{3}}{24} .
$$

Since the fixative mounting bolt resists the opening of the support node, which as a result becomes partially rigid, the angle of rotation in the node $A$ (see Fig. 2) can be determined from the formula

$$
E I \theta_{A}^{\prime}=q \frac{l^{3}}{24}-M_{A} \frac{l}{2},
$$

where is $M_{A}$ - additional bending moment that occurs in node $A$ due to the resistance of the bolt to the opening of the node.

The change of the angle of rotation in node $A$ due to the resistance of the bolted connection is defined as the difference between the values of formulas (2) and (3)

$$
E I \theta_{A}-E I \theta_{A}^{\prime}=M_{A} \frac{l}{2} .
$$

That is, the value of reduction of the opening of the support node is directly proportional to the value of the bending moment that occurs in the support part of the beam, and vice versa, the value of the bending moment that occurs in the support part of the beam is directly proportional to the value of reduction of opening of the support node.

$$
M_{A}=\frac{2\left(\theta_{A}-\theta_{A}^{\prime}\right) E I}{l} .
$$

The value of the actual opening of the hinged bolt node $A$, that is the value of the angle of rotation $\theta_{A}^{\prime}$, can be determined by considering the calculation scheme of the bolted joint in this node under the action of forces determined by static calculation of the beam (Fig. 3). The same considerations can be applied to the intermediate support of a multi-span beam (Fig. 4).

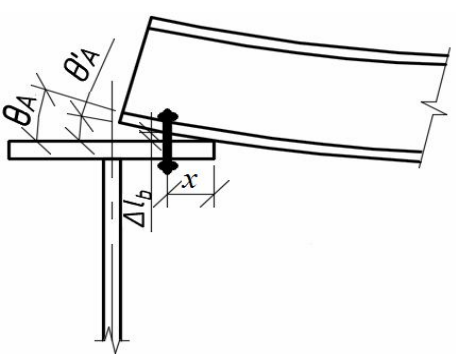

Fig. 3. Deformation of the supporting part of the single-span beam

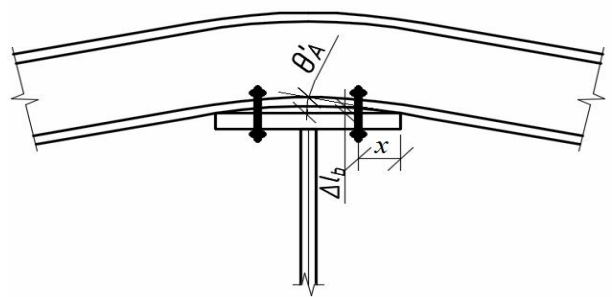

Fig. 4. Deformation of the support part of the multi-span beam on the intermediate support 
The force in the stretched bolt under the action of evenly distributed load $q$ on the beam

$$
N_{b t}=\frac{q l}{2 n},
$$

where is $n$ - the number of bolts in the connection.

Elongation of the most stretched bolt

$$
\Delta l_{b}=\frac{N_{b t} \sum t}{E A_{b n}},
$$

where is $\sum t$ - the sum of the thicknesses of the elements to be joined; $A_{b n}-$ the cross-sectional area of the bolt.

The opening angle of the flange connection in the node, the elements of which are the upper belt of the lower beam and the lower belt of the beam under consideration, and accordingly the angle of rotation of the beam in this node is

$$
\theta_{A}^{\prime}=\operatorname{arctg} \frac{\Delta l_{b}}{x},
$$

Thus, considering the calculation scheme of support of the beam in the node and determining the value of the opening angle of this connection, as well as having the selected cross section of the elements, their length and the initial opening angle of the support part, you can determine the value of bending moment in the hinged support $M_{A}$, which occurs due to the limitation of the opening of the node.

The ratio of the bending moment in the hinged support $M_{A}$ to the value of the maximum bending moment $M_{\max }=q l^{2} / 12$ for an absolutely rigid node $\frac{M_{A}}{M_{\max }} 100 \%$ indicates on what percentage increases the stiffness of the hinged support due to stresses in the fixative bolt on the support, and the rigidity of the node is

$$
k=\frac{M_{A}}{M_{\max }} .
$$

The magnitude of the dependence $\frac{2 E I}{l}$ in formula (5) is constant and indicates, that the decrease of the value of the bending moment is directly proportional to the magnitude of the decrease of the opening of the hinged bolted joint, and also depends on the length of the element, its rigidity, location of bolts in the connection, that is size $x$ - the distance from the edge of the support of the beam to the axis of the bolts in this connection (see Fig. 3).

In a beam on two supports under the action of evenly distributed load over the entire span the greatest stresses occur in the cross section in the middle of the beam length, and in multi-span continuous beams under the same load the place of occurrence of the largest value of bending moment does not coincide with the middle of the beam span. In any case, the support hinged nodes become partially rigid, and the calculation scheme of the beam changes. As a result, the value of 
the maximum bending moment in the span changes and there is an additional resource of the load-bearing capacity of the beam as a whole, which allows you to more rationally design such elements.

Summary. The data obtained as a result of theoretical and experimental studies $[3,4,5,11]$ showed that in determining the diameters of bolts in which the values of tensile stresses are close to their calculated resistance $R_{y}$ and which are located at the minimum distance from the edge of support according to requirements [1], the effect of additional bending moment on the support is almost absent. However, if you increase the diameter of the bolts, and, accordingly, their cross-sectional area, it is possible to reduce the tensile stresses in them to $0,5 R_{y}$ and, removing the bolts from the edge of the support, thus limiting the free rotation of the support nodes, to achieve rigidity of the node $k=0,035 \ldots 0,096$, which has a significant impact on the work of both the nodes themselves and the elements connected in it.

It is theoretically established that in the presence of several such nodes in the structure, its total stiffness increases by a magnitude equal to the sum of the increase in stiffness of all nodes. The calculations allow us to state that, for example, for a beam on two supports (see Fig. 1), where there are two hinged nodes, the total stiffness depending on the geometric parameters of all elements can increase by $7 \ldots 15 \%$.

Since in beams with hinged supports, the cross sections in the span are usually the most tense, taking into account the real stiffness of the hinged bolted joints on the supports allows you to redistribute the force along the length of the beam and more rationally perform its design. As a result, the stresses in the calculated sections of the split beams near the nodes will increase slightly, which makes the structure more rigid, but, at the same time, allows you to unload it as a whole; in the continuous beam, the stresses on the extreme supports will increase due to the increase in the stiffness of the nodes, and on the intermediate supports will decrease due to the pliability of the bolts.

The refined calculations proposed by this method make it possible to calculate the actual stresses in the sections, the maximum values of which are less than those calculated by the traditional method, and as a result to obtain material savings on one beam of about $3 \ldots 8 \%$. This is especially true of elements made of perforated profiles $[3,4,5]$, because the change of stress-strain state in the support zones will cause redistribution of stresses in the calculated points of their cross sections, both on the supports and in the span of the beams. This must be taken into account by including certain coefficients in the calculation formulas, depending on the specific operating conditions.

In general, the proposed method allows to determine the actual stiffness of any bolted hinge connection, taking into account its actual operation on the basis of static calculation data. In addition, it allows you to adjust the stiffness of the bolted joint by changing the diameter of the bolts, their placement or changing the estimated length of the bolts by using additional gaskets. Taking into account the additional rigidity of the nodes and, as a consequence, the structure as a 
whole, allows you to somewhat unload the elements and calculate the additional resource bearing capacity during the design of the frame elements.

\section{REFERENCES}

1. Stalevi konstruktsiyi (Steel structures). DBN V.2.6 - 198: 2014. .(in Ukrainian)

2. Eurocode 3: Design of steel structures. EN 1993-1-8:2005.

3. V. Romaniuk, V. Supruniuk. Mitsnist ta deformatyvnist perforovanykh elementiv stalevoyi arky (Strength and deformability of perforated elements of steel arch). Monohrafiya. - Rivne, NUVHP, 2013. (in Ukrainian)

4. V.Romaniuk, V. Supruniuk. Osoblyvosti rozrakhunku prolotnykh konstruktsiy z perforovanykh elementiv za skladnoho napruzheno-deformovanoho stanu (Features of the calculation of span structures from perforated elements in complex stress-strain state). Zbirnyk naukovykh prats Ukrayinskoho derzhavnoho universytetu zaliznychnoho transportu. Kharkiv, UkrDUZT, 2018. Vypusk 175. - P. 98 - 108. (in Ukrainian)

5. V. Romaniuk, V. Supruniuk. Eksperymentalni doslidzhennya prolotnykh konstruktsiy z perforovanykh elementiv za skladnoho napruzheno-deformovanoho stanu (Experimental researches of of flexible constructions from perforated elements at a complex stress-deformed state). Opir materialiv i teoriya sporud: nauk. -tekh zbirn. K: KNUBA, 2019. Vyp. 103. Pages 189-300. .(in Ukrainian)

6. Xue-Chun Liu, Fu-Yuan Cui, Zi-Qin Jiang, Xiao-Qing Wang. Tension-bend-shear capacity of bolted-flange connection for square steel tube column. Engineering Structures, Volume 20115, December 2019, Article 109798.

7. Farshad Hashemi Rezvani, Hamid Ronagh. Span length effect on alternate load path capacity of welded unreinforced flange-bolted web connections. Journal of Constructional Steel Research, Volume 138, November 2017. Pages 714-728.

8. Jia Wang, Brian Uy, Huи-Tai Thai, Dongxu Li. Behaviour and design of demountable beamto-column composite bolted joints with extended end-plates. Journal of Constructional Steel Research, Volume 144, May 2018. Pages 221-235.

9. I. Shardakov, A. Shestakov, M. Son, A. Zemlanuhin, I. Glot. Beam to column flange connection: from elasticity to destruction (theory and experiment). Procedia Structural Integrity. Volume 132018. Pages 1324-1329.

10. I. Shardakov, A. Shestakov, I. Glot. Experimental and Theoretical Study of Deformation Processes in a Flange Connection of Iron Beams. Procedia Structural Integrity. Volume 92018. Pages 207-214.

11. V. Romaniuk, V. Supruniuk. Influence of Flexibility of Bolted Joints on Rigity of the Hingeless Frame. Springer Nature Switzerland AG 2021: EcoComfort 2020, LNCE 100, Pages 371-377, 2021. https://doi.org/10.1007/978-3-030-57340-9_45.

Стаття надійшла 26.05.2021

Романюк В.В., Супрунюк В.В., Безнюк Л.І., Місюк Т.Я.

\section{ВПЛИВ ФАКТИЧНОӤ ЖОРСТКОСТІ БОЛТОВИХ ШАРНІРНИХ З'ЄДНАНЬ НА НЕСУЧУ ЗДАТНІСТЬ ЕЛЕМЕНТІВ}

В статті досліджується вплив часткової жорсткості шарнірного вузла з'єднання однопрольотної і багатопрольотної вільно обпертих балок 3 нижче розташованими конструкціями на їх напружено-деформований стан за дії вертикального рівномірно розподіленого навантаження. Вузли вільно обпертих балок за дії зовнішнього навантаження розкриваються на опорах, а монтажні болти заважають їх повному розкриттю, тобто вузли працюють як частково жорсткі. Знаючи деякі початкові параметри ідеально шарнірних вузлів, можна встановити, який вплив буде мати їх зміна як на розрахункову схему балок, так і на розрахункові схеми поперечних рам каркасів будівель і споруд, до складу яких вони входять, в цілому. Для визначення впливу опору монтажних болтів розкриттю опорних вузлів на напружений стан елементів використано метод початкових параметрів. Запропонована методика дозволяє визначити реальну жорсткість будь-якого болтового 
шарнірного з'єднання 3 урахуванням його дійсної роботи. а також регулювати його жорсткість, змінюючи діаметр болтів, міцність матеріалу, з якого вони виготовлені, їх кількість, відстань між ними, а також використовувати додатковий ресурс матеріалу за рахунок деякого зменшення максимальних напружень в розрахункових перерізах елементів. Особливо це стосується елементів, виконаних з перфорованих профілів, оскільки зміна напружено-деформованого стану в опорних зонах викликатиме перерозподіл напружень і в розрахункових точках їх перерізів як на опорах, так і в прольоті балок. Це обов'язково необхідно враховувати шляхом включення до розрахункових формул певних коефіцієнтів залежно від конкретних умов роботи.

Ключові слова: болт, з'єднання, несуча здатність, опір, жорсткість, шарнірний вузол, балка.

\section{Romaniuk V. V., Supruniuk V. V., Bezniuk L. I., Misyuk T. Y. THE EFFECT OF THE ACTUAL STIFFNESS OF BOLTED HINGED JOINTS ON THE BEARING CAPACITY OF THE ELEMENTS}

The article investigates the influence of partial stiffness of the hinge joint of single-span and multi-span freely supported beams with lower structures on their stress-strain state under the action of vertical evenly distributed load. Joints of freely supported beams under the action of external load are opened on supports and mounting bolts interfere with their full opening, that is joints work as partially rigid. Knowing some initial parameters of ideally hinged joints, it is possible to establish what influence their change will have both on the calculation scheme of beams, and on calculation schemes of cross frames of frameworks of buildings and constructions, to which they enter, as a whole. The method of initial parameters was used to determine the influence of the resistance of the mounting bolts on the opening of the support joints on the stress state of the elements. The offered technique allows to define real rigidity of any bolted hinge connection taking into account its actual work and to adjust it stiffness by changing the diameter of the bolts, the strength of the material from which they are made, their number, distance between them, as well as use additional material resource by reducing the maximum stresses in the calculated cross sections. This is especially true of elements made of perforated profiles, because the change of stress-strain state in the support zones will cause redistribution of stresses in the calculated points of their cross sections, both on the supports and in the span of the beams. This must be taken into account by including certain coefficients in the calculation formulas, depending on the specific operating conditions.

Keywords: bolt, connection, bearing capacity, resistance, rigidity, hinge joint, beam.

\section{Романюк В.В., Супрунюк В.В., Безнюк Л.И., Мисюк Т.Я.}

\section{ВЛИЯНИЕ ФАКТИЧЕСКОЙ ЖЕСТКОСТИ БОЛТОВЫХ ШАРНИРНЫХ СОЕДИНЕНИЙ НА НЕСУЩУЮ СПОСОБНОСТЬ ЭЛЕМЕНТОВ}

В статье исследуется влияние частичной жесткости шарнирного узла соединения однопролетной и многоролетной свободно опертых балок с ниже расположенными конструкциями на их напряженно-деформированное состояние при действии вертикальной равномерно распределенной нагрузки. Узлы свободно опертых балок при действии внешней нагрузки раскрываются на опорах, а монтажные болты препятствуют их полному раскрытию, т.е. узлы работают как частично жесткие. Зная некоторые начальные параметры идеально шарнирных узлов, можна установить, каное влияние будет иметь их изменение как на расчетную схему балок, так и на расчетные схемы поперечних рам каркасов зданий и сооружений, в состав которых они входят, в целом. Для определения влияния сопротивления монтажних болтов раскрытию опорных узлов на напряженное состояние элементов использован метод начальных параметров. Предложенная методика позволяет определять реальную жесткость любого болтового шарнірного соединения с учетом его действительной работы, а также регулировать его жесткость, изменяя диаметр болтов, прочность материала, из котрого они изготовлены, их количество, расстояние между ними, а также использовать дополнительный ресурс материала за счет некоторого уменьшения максимальних напряжений в рассчетных сечениях элементов. Особенно это касается элементов, выполненных из перфорированных профилей, поскольку изменение напряженно-деформированного состояния в опорных зонах вызовет перераспределение 
напряжений и в расчетных точках их сечений как на опорах, так и в пролете балок. Это обязательно необходимо учитывать путем введения в рассчетные формулы определенных коефициентов в зависимости от конкретних условий работы.

Ключевые слова: болт, соединение, несущая способность, сопротивление, жесткость, шарнирный узел, балка.

\section{УДК 624.014.2:624.078.46:624.042.062}

Романюк В.В., Супрунюк В.В., Безнюк Л.І., Місюк Т.Я. Вплив фактичної жорсткості болтових шарнірних з'єднань на несучу здатність елементів // Опір матеріалів і теорія споруд: наук.-тех. збірник. - К.: КНУБА, 2021. - Вип. 107. - С. 323-332.

Застосування запропонованої методики розрахунку, що базується на методі початкових параметрів, дозволяе визначати жорсткість болтового шарнірного з'єднання 3 урахуванням його дійсної роботи, а також змінювати ії за рахунок зміни діаметру болтів, міцності матеріалу, з якого вони виготовлені, їх кількості, відстані між ними, а також використовувати додатковий ресурс матеріалу внаслідок деякого зменшення максимальних напружень в розрахункових перерізах елементів.

Іл. 4. Бібліогр. 11 назв.

\section{UDC 624.014.2:624.078.46:624.042.062}

Romaniuk V.V, Supruniuk V.V., Bezniuk L.I., Misyuk T.Y. The Effect Of The Actual Stiffness Of Bolted Hinged Joints On The Bearing Capacity Of The Elements // Strength of Materials and Theory of Structures: Scientific-and-technical collected articles. - K.: KNUBA, 2021. - Issue 107. - P. 324-333.

The application of the proposed calculation method, based on the method of initial parameters, allows to determine the stiffness of the bolted hinge joint taking into account its actual work, as well as change it by changing the diameter of the bolts, the strength of the material from which they are made, their number, distance between them, and also to use an additional resource of material owing to some reduction of the maximum stresses in calculation cross sections of elements.

Il. 4. Ref. 11.

УДК 624.014.2:624.078.46:624.042.062

Романюк В.В., Супрунюк В.В., Безнюк Л.I., Місюк Т.Я. Влияние фактической жесткости болтовых шарнирных соединений на несущую способность элементов // Сопротивление материалов и теория сооружений: науч.-тех. сборник. - К.: КНУСА, 2021. - Вып 107. - С. 323-332.

Применение предложенной методики расчета, основанной на методе начальных параметров, позволяет определять жесткость болтового иарнирного соединения $c$ учетом его действительной работы, а также изменять ее за счет изменения диаметра болтов, прочности материала, из которого они изготовлены, их количества, расстояния между ними, а также использовать дополнительный ресурс материала вследствие некоторого уменьшения максимальных напряжений в расчетных сечениях элементов. Ил. 4. Библиогр. 11 назв.

Автор (науковий ступінь, вчене звання, посада) кандидат технічних наук, доцент, професор кафедри промислового, цивільного будівництва та інженерних споруд НУВГП Романюк Володимир Володимирович.

Адреса робоча: 33000, Україна, м. Рівне, вул. Соборна, 11, НУВГП, кафедра промислового, цивільного будівництва та інженерних споруд, Романюк Володимир Володимирович.

Мобільний телефон: +38(096) 804-31-77.

E-mail: v.v.romaniuk@nuwm.edu.ua.

ORCID ID: https://orcid.org/0000-0002-2539-4654 
Автор (науковий ступінь, вчене звання, посада) кандидат технічних наук, доцент, доцент кафедри автомобільних доріг, основ і фундаментів НУВГП Супрунюк Володимир Володимирович.

Адреса робоча: 33000, Україна, м. Рівне, вул. Соборна, 11, НУВГП, кафедра автомобільних доріг, основ і фундаментів, Супрунюк Володимир Володимирович

Мобільний телефон: +38(097) 732-99-01

E-mail: v.v.supruniuk@nuwm.edu.ua

ORCID ID: https://orcid.org/0000-0001-9534-4460

Автор (науковий ступінь, вчене звання, посада) аспірант кафедри промислового, цивільного будівництва та інженерних споруд НУВГП Безнюк Леонід Іванович.

Адреса робоча: 33000, Україна, м. Рівне, вул. Соборна, 11, НУВГП, кафедра промислового, цивільного будівництва та інженерних споруд, Безнюк Леонід Іванович

Мобільний телефон: +38(068) 336-51-68

E-mail: bezniuk ba17@nuwm.edu.ua

ORCID ID: https://orcid.org/0000-0001-6703-5062

Автор (науковий ступінь, вчене звання, посада) аспірант кафедри промислового, цивільного будівництва та інженерних споруд НУВГП Місюк Тарас Ярославович.

Адреса робоча: 33000, Україна, м. Рівне, вул. Соборна, 11, НУВГП, кафедра промислового, цивільного будівництва та інженерних споруд, Місюк Тарас Ярославович

Мобільний телефон: +38 (063) 370-73-93

E-mail: misyuk_ba14@nuwm.edu.ua

ORCID ID: https://orcid.org/0000-0003-1242-2350

National University of Water and Environmental Engineering 